\title{
Imparitas factors (gender inequality factors) in relation to women's sportleadership
}

\author{
Trenka Magdolna
}

\begin{abstract}
Absztrakt: "Teljesen világos, hogy a lányok, asszonyok számos akadállyal szembesülnek, a sportban, minden szinten" (Androulla Vassiliou, Európai Uniós Sportbiztos; 2013). Ezek a speciális nói akadályok a sportvezetésben markánsan vannak jelen. Kutatásom ezen akadályok feltárására irányult, melyeknek a leírására új konceptuális kategóriákat alkottam. (többek között az "imparitás factort", az "inter pocula-t", és a "hagyományok automatizmusát"). Ezeket szeretném a jelen tanulmányban bemutatni kvalitatív, nóközpontú , kritikai feminista alapokból kiinduló kutatásom eredményét. Az "imparitás factorokat", mint gyúitőfogalmat alkottam meg, a speciális, strukturális-funkcionális nói akadályok (impedimentumok) öszszefoglalására. Az "imparitás factorok", alá több új fogalmi kategóriát határoztam meg, ebból mutatok be most hármat. Az "inter pocula-t" a "hagyományok automatizmusát"; és a "közéleti patriarchizmust"; melyek egyszerre írják le és egyben magyarázzák is a női esélyegyenlótlenséget a (sport)vezetésben. Az "inter pocula" mint új strukturális-múködési metafora használatával, lehetóvé válik a probléma többoldalú megközelítése. A másik új kategória a "hagyományok automatizmusa" modellezi a sportvezetésre különösen is jellemzó, patriarchális, tekintélyelvú múködési mód hatását, folyamatos újra termelódését. Az "imparitás factorok" közé sorolt harmadik akadályt, "közéleti patriarchizmusnak", neveztem; ennek a kategóriának a nevét Walbytól (1994) 'kölcsönöztem', azonban az ezzel a kategóriával leírt jelenség - a politikai és gazdasági eliteknek a magasabb sportvezetői posztok iránt megnyilvánuló 'élénk érdeklódése', mint új nói akadály - teljes mértékben a saját kutatásom eredménye. Az új kategóriák bevezetése - reményeim szerint - hozzájárul a sportban zajló folyamatok mélyebb megértéshez; és így, ezen keresztül, elvezet ezen nói akadályok lebontásához. A sportvezetésben a nók helyzetét eddig még csak a nemzetközi sporttudományban vizsgálták. Komplex, és hazai vizsgálat még nem volt. Ez adja a téma abszolút újdonságát.
\end{abstract}

Kulcsszavak: nemek közti esélyegyenlőség, kritikai feminizmus, sportvezetés, imparitás faktorok, közéleti patriarchizmus

\begin{abstract}
It is clear that girls and women still face numerous barriers when it comes to participating in sport at all levels...".(Androulla Vassiliou, European Commissioner responsible for sport; 2013). These special female barriers are significantly present in the case of sport leadership. The present research was designed to explore these barriers, for the description of which some new conceptual categories were created (such as the "imparitas factors", the "inter pocula", the "automatism of traditions", etc.). In the present study, I would like to introduce them based on the research deriving from a qualitative, women-centred, critical feminist approach. The "imparitas factors" were created as a generic term for summarizing the structural-functional female barriers (impedimentum); such as the background of female inequality. Under this new generic term ("imparitas factors"), a number of new conceptual categories were determined; three of them to be discussed in the paper: the "inter pocula", the "automatism of traditions", and the "public patriarchy"; which simultaneously describe and also explain women's inequality in (sports) leadership. The "inter pocula" being used as a new structural and operational metaphor, makes it possible to approach the problem from several viewpoints. The other new category, the "automatism of traditions" models the effect of the patriarchal, authoritarian mode of operation particularly present in sports leadership, and its continuous re-production.
\end{abstract}


The third female barrier listed among "imparitas factors" is called category of "public patriarchy"; the name of which was borrowed from Walby (1994), but the phenomenon described in this category, i.e. the 'intense interest' of the political and the economic elites for higher sport leadership positions, as a new female barrier, is entirely the result of my own research. The introduction of the new categories hopefully can contribute to an indepth understanding of the processes taking place in the sport; and in this way, leads to the breaking down of these female barriers. The situation of women in sports leadership has only been investigated in international sports science, complex research has not been carried out in Hungary, which underlines the relevance of the topic.

Keywords: gender equity, critical feminism, sports leadership, imparitas factors, public patriarchy

\section{Bevezetés}

A múlt század nyolcvanas évei óta kibontakozóban lévő nőtudomány, (women's studies) - bár még mindig nem az értéken elismert módon - napjainkra már markánsan, a sportra is kiterjedő, nőkutatásokkal is jelen van a társadalomtudományok között. A women's studies-t müvelők ugyanakkor szüntelenül szemben találják magukat a hárítás legkülönfélébb formáival: a női esélyegyenlőség témájának leértékelésétől, a nemek szembeállításának vádjáig; a kérdéskör elavultnak bélyegzésétől (felesleges rá szót vesztegetni, hisz már régen megvalósult), az individualizáció stigmájáig (ugyan már, az ismerőseim vagy én magam nem érezzük magunkat nőként, hátrányban) igen széles a skála. Magam is találkoztam ezzel az attitűddel, amióta a women' studies-t művelem. Jelen tanulmányban a kutatásom eredményeként általam kreált új konceptuális kategóriákat ("imparitás factort", "inter pocula-t" és a "hagyományok automatizmusát") szeretném bemutatni. Az "imparitás factorokat", mint gyüjtőfogalmat alkottam meg, a speciális, strukturális-funkcionális női akadályok (impedimentumok) összefoglalására. Kutatásom nyomán, öt ilyen "imparitás factort" nevesítettem. Öt, speciális, (jellemzően) nőkkel szembeni akadályt (impedimentumot) soroltam az "imparitás factorok" közé, melyeket új fogalmi kategóriák (metaforák/allegóriák) bevezetésével definiáltam, írtam le. Ezen női akadályok közül most hármat mutatok be. Az "inter pocula-t" a "hagyományok automatizmusát"; és a "közéleti patriarchizmust". (A további két impedimentum bemutatása meghaladná jelen cikk terjedelmi kereteit). Az "inter pocula (poharazás közben), mint új kategória egyszerre jelenti az évezredek alatt megkövesedett, férfijogú, patriarchális struktúrát, és írja le annak rejtett (Merton, 1980) működését, metaforaként. A "hagyományok automatizmusa" a patriarchális, tekintélyi modell újratermelődését magyarázó, annak szimptómáit leíró új kategória. Az "imparitas factorok" közé sorolt harmadik női akadályt, "közéleti patriarchizmusnak", neveztem; ennek a kategóriának a nevét Walbytól (1994) 'kölcsönöztem', azonban az ezzel a kategóriával leírt jelenség - a politikai és gazdasági eliteknek a magasabb sportvezetöi poziciók iránti 'élénk érdeklödése', mint új nöi akadály - teljes mértékben a saját kutatásom eredménye. Ezen új fogalmi kategóriák, a mögöttük álló jelenségek mélyebb és teljesebb megértését kívánják elősegíteni. Jelen cikk továbbá arra is felhívja a figyelmet, hogy a nők esélyegyenlőségének kutatása, a "nö" kérdés napirenden tartása ma is időszerü, a sportban különösen az, tekintettel arra, hogy a nemek közötti esélyegyenlőség még ma is csak elérendő álom. Az Európa Tanács Miniszteri Bizottsága 1988. novemberében „Nyilatkozat”-ot fogadott el „A nök és férfiak egyenjogúságáról"; Ebben megállapították: "...noha a nök és férfiak egyenjogúsága az ember személyiség jogainak egyik alapelve melyet, mint alapvetö jogot, az Európa Tanács tagállamai alkotmányaikban és nemzeti törvényeikben garantálnak”, „...a nök és férfiak közötti egyenlötlenségek mind jogilag, mind ténylegesen továbbra is fennállnak". Azóta közel negyedszázad is eltelt és azt kell megállapítani, hogy ezek a szavak ma is érvényesek. Különösen a sportra, mint speciális társadalmi alrendszerre azok. Talbot, svédországi tapasztalatok alapján kijelenti: "... a nöi egyenjogúság kérdése a sport területén elmarad a társadalmi vagy a kulturális (söt az egyházi) élet más területén tapasztaltaktól." (Talbot, 2000, 107.). A téma tehát abszolút időszerű. 


\section{Módszerek}

Kutatásom célja a sportvezetés/sportdiplomácia női szempontú vizsgálata. „A sportszervezet vonatkozásában is végeztek már elemzéseket, melyek világosan bemutatják, hogy a nök hátrányos helyzetben vannak a férfiakkal szemben, a lehetöségek és a poziciók vonatkozásában" (Talbot, 2000, 105.). A vizsgálódás nézőpontja ebből a hátrányos helyzetből való - kritikai - reflexiót jelent. Kijelenthető, Radford Ruether analógiája nyomán: a kutatási folyamatban a vizsgálati nézőpontnak, így a nőközpontú 'point of view'-nak sincs véglegesen lezárt definíciója ( $B u$ day, 2001). A nőközpontú vizsgálati nézőpont kritikai aspektusú; azaz, rá kíván mutatni az elfogult androcentrikus gondolkodás egyoldalúságára, mely a sportban, mint a hagyományosan férfi dominált társadalmi alrendszerben az évszázadok során kialakult. A nőközpontú 'point of view' jelenti továbbá: az eddig leginkább a férfiak tapasztalatára épülő és ezáltal meglehetősen torz - megállapítások helyett egy egyetemes szemléletmód alapján történt értékelést. A nőközpontú vizsgálati módszer egyben felmutatja a patriarchizmusnak nőkre és férfiakra gyakorolt, egyaránt ártalmas hatásait. Ugyanakkor a legcsekélyebb mértékben sem férfiellenes, és a legteljesebb mértékben keresi a párbeszéd lehetöségét. Ez adja a feldolgozás módszertani újdonságát. A kritikai (feminista) megközelítés szerint a női lét vizsgálatához elengedhetetlen maguknak a nőknek a meghallgatása, ezért a kutatásban sportvezető nőkkel készítettem interjúkat, melyeket úgy használtam, mint a kvalitatív kutatások egyik, gyakori módszerét. Az interjúk feldolgozásánál, a CDA-t, alkalmaztam, a kritikai diskurzuselemzést, (critical discourse analysis - CDA) mely nem deskriptív, hanem interpretatív, azaz értelmező, tehát diszkurzív módszer. Mivel a kutatási területem a nők sajátos helyzete a társadalom egy speciálisan férfuralmi területén (sportvezetés), a CDA mint értelmezési keret alkalmazása kézen fekvő volt, hiszen a módszer egyik fó alapelve szerint a hatalmi relációknak diszkurzív megjelenése is van.

\section{A téma újdonsága}

A férfiak által dominált sport(vezetés) rejtett mechanizmusainak vizsgálata kapcsán Nancy Théberge, 1991-ben, egy sportszociológiai konferencián felidézte Hargreaves elhíresült megállapításait: "...az olimpiák története a hatalom, az elitizmus, a megszállottság, a túlzások, a megosztottság, és a kizsákmányolás története." Továbbá "...az olimpizmus férfi sovinizmussal, férfi dominanciával teljes" (Théberge, 1991, 1.). Az élsportot azóta még inkább a túlzások, a megszállottság, az (ön)kizsákmányolás jellemzi. És továbbra is jelen van a férfi dominancia; mint „a harc” modern formája. A sport feminista kritikája szerint „,a szexizmus a sportban kulturális és strukturális interakciós formákban” (Kovács, 2009, 65.) van jelen. Érdeklődésem központjában azok a strukturális, kulturális tényezők állnak melyek a nők sportvezetővé válásában, ottani sikerességükben vagy éppen kudarcaikban szerepet játszanak. Az elmúlt 20-25 évben természetesen sok változáson ment keresztül a sport; döntően üzletivé vált. A sportszervezetek pedig egészen hasonlóan kezdtek működni, mint a gazdaság egyéb vállalatai. A sportolónők számának növekedése értelemszerűen maga után vonta, hogy nők is megjelentek az edzői, a sportvezetői „karban”. Azonban csaknem ugyanazokkal - a kisebbségi létből fakadó - problémákkal találták magukat szemben, mint a sportoló nők, már úgy 30-40-50 éve. Korábban számos vizsgálat, tanulmány készült a sportoló nők férfiakéhoz képest marginális helyzetéről (pl.: Théberge, 1991, Pfister, 2003, Talbot, 2000); napjainkban az edzőnők (Bodnár, 2012) sajátos problémáival kapcsolatban. Az Európai Unióban pedig manapság kezdik vizsgálni a nők döntéshozatalban és végrehajtásban betöltött szerepét. Ez lassanként megjelenik a sport területén is. Azonban mindezideig senki nem foglalkozott az egalizálódó női versenyzői arányok elemzésével, egészen konkrétan a nők sportvezetői /sport diplomataként/ marginális helyzetével, annak okaival. Átfogó és komplex nőkutatás, a sportvezetőnő-kutatás mint téma abszolút újdonságnak tekinthető. Ebben a tanulmányban néhány új összefüggésre és az ezek definiálására kreált új konceptuális kategóriák bemutatására vállalkozom.

\section{Eredmények}

1. Megérteni a szabályokat, avagy az "inter pocula" jelensége, mint esélyegyenlötlenségi tényezö - "imparitás factor"- I.

"A nöknek ...meg kell érteniük a szabályokat, ha a folyamatokat irányitani kivánják." (Talbot, 2000, 99.). E nélkül nincs esélyük eredménnyel kandidálni vezetői pozíciókra; e nélkül nincs esélyük az esetleg, - kivételként - mégis elnyert vezetői 
tisztségükben sikeresnek lenni. A férfitársadalom szabályai szerint, századok óta lényegében változatlanul, /kvázi zárt klubként/ működnek ma is a politikai, gazdasági, sport és művészeti elitet leképező társaságok, szövetségek, pártok, egyéb szervezetek. A status quo jól jön a férfiaknak. Mindennemű változás ugyanis a férfiak - vezetöi - sikerét veszélyezteti. „Ezért alapvetö létérdekük a nöi versenytárs megjelenésének és sikeres adaptálódásának tudatos vagy tudat alatti akadályozása." (Koncz, 2011, 39.). A férfiak - a patriarchális társadalmi struktúrák mentén - „monopolizálták a hozzáférést és az ellenörzést az élet alapvetö lehetöségeinek intézményes meghatározóihoz, különösen a gazdaság és az állam területén". (Dunning, 2002, 141.). Ez az évszázadok óta változatlan strukturális meghatározottság, forrása és alapja a férfiuralomnak.(Bourdieu, 2000). Mely a sportban, sportvezetésben is, markánsan jelen van

Ezt, a strukturális meghatározottságot, és egyben müködési módot irom le, egy kategóriában: az "inter pocula" terminológiával, benne nevesítve a jelenség két oldalát. Ugyanis így, az új struktúra müködés, metafora használatával, egyszerre válik lehetővé a probléma többoldalú, újszerủ megközelítése, bemutatása, mely elvezethet a Talbot által is elengedhetetlennek tartott megértéshez.

\section{A fogalom definiálása}

$\mathrm{Az}$ "inter pocula" (poharazás közben), mint új kategória: egyszerre jelenti az évezredek alatt megkövesedett, férfijogú, patriarchális struktúrát, annak rejtett működését, melyet metaforaként jellemez, azaz, a tisztségek, posztok, beosztások és szerepek „poharazás közbeni”, terített asztal melletti le- és kiosztását. Ahol a hatalom struktúrái, az informális kapcsolatok, a kapcsolati tőke az elsődleges; ezért a nők (sport)vezetővé válásának lehetőségét markánsan, mögöttesen, és nagyfokú látenciában - gátolja.

Az "inter pocula" mint strukturált hatalom, és mint rejtett (Merton, 1980) müködési mód

A (sport)vezetővé válás rögös útján a döntő elem a (ki)választás kérdése. Az esélyegyenlötlenség gyökere ugyanis elsődlegesen a vezetői - hatalmi - posztokra történő kiválasztásban, a betöltés (eljárási) rendjéből adódik. Kutatások „....kimutatták, hogy a szervezeten belüli elörejutást a szervezeti elit kontrollálja, és a hiedelmekkel ellentétben nem az egyének nyillt versenyéböl kerülnek ki a magasabb pozíciókat elnyerök." (Bodnár, 2012, 111.). Vizsgáltam és úgy találtam, hogy a 'lex sportiva', a sportszervezetek tagsági, jelölési (kandidálási) írott szabályai még mindig férfijogú struktúrákat tükröznek. A vezetővé válás - íratlan - szabályai pedig még inkább patriarchálisak. Ezt fel és el kell ismerni. „... az öltözökben, az igazgatósági szobákban megismételt szervezeti kultúrák ténylegesen marginalizálják a nök szerepét, karrierlehetöségét ...". (Talbot, 2000, 95.). Hollandiában edzők között kutatást végeztek, arra kiterjedően, ki hogyan került a klubhoz: a hétszázhúsz megkérdezett edzőnek csak 5\%-a került a klubjához hirdetés útján (Knoppers és Elling, 1999, in: Bodnár, 2012, 116.), a többiek informális, kapcsolati úton nyerték el az állást. A posztra történő kiválasztás „...informális jellegét, a döntés személyes hatáskörét azzal is hangsúlyozzák, hogy az állástárgyalásokra legtöbbször az egyesület bárjában került sor. Lényeges, hogy már az álláslehetöségröl sem tudhat(ott) a szakma széles köre, csak a beavatottak. Azok, akik egy bizonyos kapcsolati és információs hálónak, vagyis az in-groupnak tagjai voltak" (Bodnár, 2012,116 .). A hollandiai eset, igaz nem vezetői kiválasztásról volt szó, de egészen pontosan mutatja a sportban müködő strukturális meghatározottságot, patriarchális működési mechanizmust. Ez maga az "inter pocula", a sajátos, kettős arculatával; melyet a következőkben elemeire bontva is bemutatok. A modern sport része a gazdaságnak, számos kapcsolódási pontja van az állammal, az adminisztratív és pénz hatalommal egyaránt. A sportvállalkozások hasonló módon működnek, mint a gazdasági nagyvállalatok. Kanter (1977) vizsgálta a férfi-női szerepeket nagyvállalatoknál. (szervezeti modell). Megállapításait a „male homosociabilitás” kategóriájával írta le: azaz a szervezetekben a hatalmat (döntően) zárt férfitársaságok tarják meg maguknak (Giddens, 2008). A sportban, sportvezetésben is jelen vannak ezek a zárt férfitársaságok és sajátos patriarchális szokásjoguk szerint működnek. Idegent, nőt nem szívesen - engednek maguk közé; a szegregáció mögött „a világ legkülönlegesebb férfi klubjának fenyegetettsége áll" (Kovács 2009, 65.), nyilatkozta az egyik sportvilágszervezet vezetője, a nők adott sportágban való diszkriminációja kapcsán. „... a nök továbbra is - pozíciójuktól függetlenül - egy szimbolikus negativ hányadossal vannak elválasztva a férfiaktól". (Bourdieu, 1990, in: Hadas, 2002, 181.). A hatalom a demarkációs vonalakban és az ezeket fenntartó gondolkodási rendszerekben rejtezik (Alvesson és Deetz, 1998). A hatalom az egyének vagy egy 
csoport tagjainak az érdekérvényesítő képessége; azaz az a képesség, hogy bizonyos célokat elérjenek - pl.: vezetővé váljanak -, a körülményeket a céljaiknak megfelelően alakítsák (Giddens, 2008). „...a férfiak a nökénél lényegesen több hatalomforrást (személyes kapcsolatok, eröforrások birtoklása, mint pénz, információ) akkumuláltak a társadalmi munkamegosztásban betöltött szerepeik és tevékenységük során." (Koncz, 2011, 39.).

Mindezek miatt az "inter pocula" által ábrázolt jelenség, a nők számára versenyhátrány jellege vitathatatlan: a nők a tisztségek, posztok, beosztások 'poharazás közben, teritett asztal mellett' történő szerep le- és kiosztásából ki vannak rekesztve (részben vagy egészében), a sportban is. Tehát már a sportvezetővé válásuk elején, a startnál' szembesülniük kell a szegregáció különféle formáival. „...az anomália abból ered, hogy a sport kulturális koncepciói maszkulin természetüek, amelyben nincs helyük a nöknek..." (Kovács, 2009, 65.).

A maszkulin sportvezetés, a hatalmi osztozásból, legtöbbször kihagyja a nőket.

Először, mert nőket eleve ritkán vonnak bele a 'poharazás közbeni' háttér alkukba. (Ha csak nem egyéb céllal hívják meg őket...). Az egyik férfi (sporttárs, sportújságíró, sportvezető stb.) a másikat minden további nélkül, elhívhatja egy korsó sörre, egy golf meccsre, utána szaunázásra ${ }^{11}$, wellness partira stb., közben mindketten „érdeket érvényesítenek”. „...egy férfi sokkal nagyobb mestere annak, hogy pozícionálja magát!" fogalmazta meg a realitásokat egyik interjúalanyom. A sör, szotyi, foci lobbi léténél fogva, sajátosan a férfiak eszköze, a maszkulinitás megnyilvánulási terepe; ”...a férfiak játéka..." definiálta tömören ugyanaz a sportvezetőnő. Megjegyzendő, Bourdieu használta a játék' kifejezést (Bourdieu, 1990, in: Hadas, 2002, 181.) a férfiak által a nők kirekesztését megjelenítő hegemón maszkulinitás megnyilvánulásaira.

Másodszor azért sem vonják be a nőket ezekbe a háttéralkukba, mert, az "inter pocula"-hoz szükséges és elégséges hatalommal, érdekérvényesíto" potenciállal a nők nem rendelkeznek; nincs értelme hatalmi osztozásra olyanokat hívni, akiktől viszont támogatás nem remélhető csekély befolyásuk miatt. A hatalmi 'játszmák' aktoraitól elvárás a kölcsönösségi alapon történő viszonosság, ahogy azt az interjúalanyaim közül többen konkrétan megfogalmazták.

\footnotetext{
${ }^{1}$ Sokáig tematizálta a sajtót a hir, mely szerint az egyik magas sportvezetöi poszt miként „kelt el” az igéretek szintjén, szaunázás közben.
}

Így aztán nem meglepő, hogy az "inter pocula" a nőket sújtja elsődlegesen. (A kimaradó férfiakat is természetesen, mert a férfiak között is vannak olyanok, akiknek nincs elég hatalmuk, 'körön belülre', az 'in-group'-ba, bekerülni.).

Az "inter pocula" egy ritkán nevesitett, - elhallgatott-sajátos arca.

A megkérdezett sportvezetőnők, egyben azzal is tisztában voltak, hogy nőként az "inter pocula"tól - saját döntés okán is - legtöbbször, távol kell maradniuk. „Az természetes, hogy a férfiak az üzleti partnereiket éjszakai szórakozóhelyekre viszik, ugyanakkor ezek a programok a nök számára elképzelhetetlenek" (Sümegi, 2007, 43.). Jól mutatja, hogy mennyire nem egyenlők a nők, hogy „...még ma is nehéz egy szórakozóhelyre a nönek úgy elmenni, hogy az ne járjon státuszvesztéssel, vagy ne provokálja ki a férfiak nem kivánt figyelmét. Ez ... az évszázados férfiuralom eredménye, és azé a társadalmi rendszeré, ami továbbra is él, és ezt az uralmat tükrözi, illetve szilárditja meg." (Dunning, 2002, 148.). Ez a müködő férfiuralom, a mai napig korlátozza - a nőket minden területen -, témánk szempontjából, vezetővé válásuknak már esélyeit is. Jól tudjuk, hogy egy-egy sportesemény kapcsán a vezetők és a sportolók milyen éjszakai ünnepléssel, mulatozással 'kapcsolódnak ki'. Viszont ezeken az alkalmakon nem „szerencsés” nőként részt venni; magára valamit adó nő az ilyen 'buliktól' önként marad távol. Akkor is, ha ezzel esetleges előrelépési esélyeit csökkenti. Az edzőnők között végzett, már hivatkozott kutatás, a nők önkéntes távolmaradását, az "inter pocula"-tól, hátrányként definiálja, „mert az informális kapcsolatoknak a müködtetése és megerösitése is ekkor történik." (Bodnár, 2012, 116.).

Az informális kapcsolatok jelentősége a sport egészében nagy szerepet kap. A döntéshozók ugyanis jellemzően, döntően, nagy kapcsolati hálóval, hatalommal rendelkező, az "inter pocula"-t, rutinosan használó férfiak. Még ha testületi döntésről van is szó, a háttérben mindig találhatunk olyan hatalmi potenciállal bíró személyeket, akiktől a választás kimenetele függ. Ezeket a személyeket különböző módokon lehet megnyerni; így 'poharazás közben' különösen is.

Férfi-nő relációban a befolyásolás ilyen módja félreértésekre, szexuális zaklatásra adhat okot és módot. Egy sportvezetőnő - magánbeszélgetésben - spontán fogalmazott így: ”...minden tisztességes 
eszközt felhasználok (az elörejutásáért), de nem fogok lefeküdni senkivel ezért". Nem gondolom, hogy a sportvezetői tisztségeket 'kanapén osztják el', de a nők sportkarrier építése során - sajnos - nem zárható ki a különféle nemi zaklatások lehetősége. És nem csak a kiválasztás során, hanem a sportvezetői tevékenység idején is előfordulhat zaklatás. Az interjúk során többször tapasztaltam, hogy a nyilatkozó sportvezetőnők közül többeket ért sportéletükben szexuális molesztálás. Egyikük hosszabban is beszámolt arról, (a zaklatókat nem nevesítve), hogy mind idehaza, mind a nemzetközi sportvezetésben folyamatosan többektől, számos alkalommal szexuális zaklatásnak volt kitéve. „...ez végig kisérte az életemet...", mondta az interjúalanyom végtelen szomorúsággal. A jelenség tehát létezik - mondhatjuk, hogy köztünk él - csak nem, vagy keveset beszélünk róla. Jelen kutatás sem terjed ki ennek a területnek (nemi zaklatások, abúzusok) a vizsgálatára; ez olyan hatalmas és a téma fó vonalától eltérő irány, hogy erre nem vállalkozhat egy pilot study; csak mint az "inter pocula" sajátos oldalát mutathatja be.

\section{A "hagyományok automatizmusa", mint} esélyegyenlötlenségi tényezö - "imparitás factor"II.

Jelen kutatás nyomán az látszik, hogy van egy további oka a nők alacsony sportdiplomáciai, illetve felső sportvezetői pozíciókban való marginális jelenlétének. Mégpedig az, hogy bizonyos posztokat a hagyomány szerint csak férfiak tölthettek be. A tapasztalat az mutatja mind a diplomáciában, mind a sportban, hogy a hagyománynak igen nagy, máig élő, determináló szerepe van. „... a sport marad a közélet egyik legkonzervativabb, és legkevésbé rugalmas területe, amely messze elmarad más társadalmi struktúrák mögött". (Talbot, 2000, 91.).

A nemzetközi társadalomtudományban - a természettudományok nyomán, az interdiszciplináris területeken - legújabban "mémeknek” nevezik azt a kifejezést, melyet itthon Falus András biológus terjesztett el, és jelentése szerint az epigenetikusan átöröklődőnek tartott egyes társadalmi-szociológiai elemeket értjük alatta. Ilyennek tartják például a „férfi tekintély” öröklődéséhez kapcsolódó szimptómákat. A patriarchális, tekintélyi modell működési módját, újratermelődését leíró új kategóriát: a "hagyományok automatizmusának" neveztem, két dolgot értve alatta:
- A hagyomány a férfinak eleve magasabb státuszt, tekintélyt tulajdonít, melyet a társadalom mechanikusan fogad el. A nőknek aktuálisan mindig meg kell harcolni a tekintélyükért, míg a férfiaknak pusztán férfi mivoltuk okán, erre nincs szükségük.

- A hagyományok alapján a döntéshozók - sőt sokszor maguk a hátrányosan megkülönböztetett nők is (!) - azt feltételezik a férfiakról, hogy alkalmasabbak vezetői pozícióra, mint a nők. Egyik, az általam megkérdezett csúcs sportvezetőnő, a beszélgetés során, mikor arról esett szó, hogy itthon még a szinkronúszó szövetség elnöke is férfi, egy spontán, automatikus reakciójában - láthatólag maga is meglepődve, mit is mondott - kijelentette: "...célszerübb férfit választani..." (elnöknek).

Íme a hagyományok automatizmusa, a maga teljes és egészen konkrét valóságában.

Egy másik, a hagyományok automatizmusának működését jól jellemző történés: 2013 nyarán az egyik csapatsportban, új kapitány kinevezése vált szükségessé. Nem a csapattal addig dolgozó másodedző(nőt) nevezték ki, hanem egy másik személyt, egy olyan férfit, aki kétségtelenül alkalmas a pozíció betöltésére. A másodedzőnő, a várható döntést megelőzően maga nyilatkozott úgy sajtóban: „...valahol úgy éreztem, még nem állok készen a válogatott kapitányi feladatra. Még sok mindent meg kell élnem hozzá, hogy ezt a feladatot jól tudjam végezni." Kérdés, hogy egy negyvenes, a sportágban 'megöregedett', tapasztalt nő miért nem tartja magát az első vonalra felkészültnek? Pedig aki alkalmas a vezető közvetlen munkatársaként dolgozni, aki alkalmas a távollévő vezetőedzőt önállóan helyettesíteni, és ezt már többször be is bizonyította, kinevezhető lett volna a kapitányi posztra. Egy negyvenes férfinak - hasonló- sport(vezetői) múlttal, vélhetőleg eszében sem jutna, hogy „alkalmatlan” lenne. Ebben a konkrét esetben is kimutatható "hagyományok automatizmusának" mindkét aspektusa:

- A döntéshozók (mind férfi) maguk is - első vezetőnek a válogatott mellé - „automatikusan” alkalmasabbnak, tekintélyesebbnek látták férfitársukat. Holott először mindenki kezdőként indul el az első vonalbeli vezetői munkában. Ugyanebben a szituációban vélhetőleg egy 'férfi' másodedző bizalmat kapott volna. Az adott sportágban megtörtént már a múltban, hogy 'beugróként' férfi lett az első számú vezető, tehát 
konzerválódott ez a modell.

- Az előzőekben hivatkozott nagyon gyakori jelenség, hogy maga az érintett nő sorolta magát a 'második sorba', a férfijelölteket alkalmasabbnak ítélve. Nagyon valószínű, hogy itt nem pusztán az adott sportvezetőnő személyes 'gátlásairól' van szó, hanem egyfajta 'társadalmi' megfelelési kényszerről; no meg a realitásról (vagy előítéletről), hogy nem ő lesz a befutó.

\section{A "közéleti patriarchizmus" (Walby, 1994,} in: Andorka, 2006, 368.), mint esélyegyenlötlenségi tényezö - "imparitás factor"- III.

Ahogy a bevezetőben már jeleztem, a most bemutatásra kerülő, az "imparitas factorok" közé sorolt harmadik akadálynak a nevét, a "közéleti patriarchizmust", Walbytól (1994) 'kölcsönöztem', azonban az ezzel a kategóriával leírt jelenség - a politikai és gazdasági eliteknek a magasabb sportvezetöi posztok iránt megnyilvánuló 'élénk érdeklödése', mint új nöi akadály-, teljes mértékben a saját kutatásom eredménye. A pályafutásukat befejező élsportolók egy része érthetően sportvezetői vagy edzői karrierben gondolkodik. Samaranch volt NOB elnök óta ezek a sportemberek némi előnyt is élveznek a többiekkel szemben. Mellettük megjelentek a magasan képzett - de nem feltétlenül volt élsportoló - sportszakemberek. Mindkét csoportnak szembesülnie kell azonban azzal, hogy sportvezetőnek lenni nem pusztán, és nem elsődlegesen sportszakmai tudás kérdése. A sportban a vezetővé válás hordoz egy konkrét sajátosságot: a sportszervezetek, mint munkahelyek kevésbé szabályozottak: struktúrájuk, foglalkozási szerepeik nincsenek konkrétan - normatívan - meghatározva, így a vezetők formális és informális mozgástere lényegében kötetlen (Bodnár, 2012). Mindezek miatt egy-egy sportvezetői posztra a kiválasztás nem nélkülözi a szubjektív elemeket. Nincs olyan norma, mely a sportszervezetekben, és még inkább a sportklubokban, sportegyesületekben, a vezetővé váláshoz elengedhetetlen, konkrét, adekvát, szakmai feltételeket szabna meg. Míg egy kórházigazgató rendszerint gyakorlattal rendelkező orvos, esetleg tapasztalt közgazdász, addig a sportvezetővé váláshoz nem elengedhetetlen a Testnevelési Egyetem-i vagy egyéb diploma, sőt a sportszakmai gyakorlat sem kötelező. A sportmúlt előny, de ez sem feltétel. Tehát tisztázatlanok az adott sportvezetői poszt vonatkozásában az 'indulási' feltételek. Ez a nőknek nem kedvez; tehát ez egy olyan speciális versenyhátrány a számukra, mely - a sportvezetés körül felbukkant, politikai és gazdasági elit (lobbi) tevékenységével összefüggésben - az utóbbi időben fokozódott. Számos sportszövetség vezetőjének (elnök) köze nincs az adott sportághoz. Van viszont jelentős gazdasági, politikai potenciálja. Több évtizedes sportvezetői gyakorlattal rendelkező, neves, volt élsportoló-olimpikon (férfi) nyilatkozta: „Bejön egy dilettáns (a szakszövetségbe) és elnök lesz, politikai vagy szponzori hátszéllel...". Az utóbbi évek tapasztalata ezt megerősíti: azaz sportvezetőnek lenni nem elsődlegesen az egyéni alkalmasság hanem, politikai-hatalmi kérdés. Mint azt az előzőekben már láttuk, a nők hatalmi potenciálja, társadalmi tőkéje, az "inter pocula"-ként meghatározott jelenségek nyomán (is), jelentősen kisebb, mint a férfiaké. A megkérdezett sportvezetőnők közül többen is elismerték, hogy az ő lobbi erejük nem versenyezhet a férfiakéval. Ezért a nők számára kedvezőbb a formális, normatív kiválasztási rend. Maguk a megkérdezett interjúalanyaim is jobban bíznak ebben, ezért is tartozik vezetői attitűdjükhöz a lifelong learning (az élethosszig tartó tanulás) mint a vezetői kiválasztásnál a versenyhátrányukat kompenzálandó egyedül mérhető elem. Ugyancsak az előző neves magyar férfi sportvezető mondta még 2009-ben a következőket: „a magyar sportirányitás prostituálódott-tisztelet a kivételnek - politikailag megosztott, befolyásolt és kiszolgáltatott”. A politika befolyása gyakran a személyi döntésékre is kiterjed. Egy másik tradicionális sportágban, a nemzetközi sportszövetségében, a közelmúltban tisztújítás révén újabb ciklusra megbízást elnyert, magyar (férfi) sportvezető pedig így jellemezte a választást: "...soha korábban nem szólt bele ennyire a választásokba a politika, a pénz, az intrika, mint manapság”. A politikai (és a gazdasági) elit tehát markánsan megjelent a sportvezetés körül. Közvetve vagy közvetlenül. Ez az újdonsült és erőteljes érdeklődés ezen elitek részéről a sport - felső - vezetői pozíciói iránt jól jelzi, hogy a sportvezetés hatalommal, tekintéllyel, nem utolsó sorban magas jövedelemmel kecseget. Egyben azt is jelenti, hogy a sportban a nőknek egyre fogy az esélyük, hogy valaha is egyenlő helyzetből indulhatnak a senior posztokért. A női esélyegyenlőtlenség hátterében döntően a hatalom hiánya áll. „... a hatalom az egyenlötlenség alapvetö formája... " (Lenski, 1966, in: Andorka, 2006, 161.). Ismert az axióma: „soha nem volt olyan társadalom, melyben a nök nagyobb hatalommal birtak, mint a férfiak" (Giddens, 
2008, 363.). Nekik ugyanis rendszerint egyáltalán nincs elegendő hatalmuk (kapcsolatrendszerük, politikai tőkéjük), így azonos esélyük sem, hogy kandidáljanak magas sportvezetői pozíciókra; tehát még a formális kiválasztási rendben, pl.: pályáztatás esetén is hátrányból indulnak. Az interjúalanyaim közül többen is rámutattak erre a női hatalmi deficitre, amely anyagi-egzisztenciális deficit is egyben. Egyikük így fogalmazott: „...ha körülnézel az elnökök körül a sportágakban, (akkor látható, hogy az elnök) vagy olyan politikai kapcsolatokkal rendelkezik, vagy olyan egzisztenciával", amilyennel egy nő nem rendelkezik. Így érthető meg az a hátrány, amiből a nők indulnak (ha egyáltalán a lehetőségig eljutnak) egy-egy sportvezetői tisztségért. A strukturális egyenlőtlenséget csak fokozza a politikai és gazdasági elit megjelenése a sportvezetésben. Mivel pedig a gazdasági és/vagy politikai elit is, jellemzően - hatalommal (vagyonnal) rendelkező - férfiak által dominált, kevéssé valószínű, hogy a hatalmi potenciállal nem rendelkezö, 'out-group' csoport tagjai (jellemzően nők) közül támogasson valakit ez a két elit. Jól látható az is, hogy döntően ugyanaz a férfiakból álló elit „mozog” valamennyi alrendszerben, a magas jövedelmű, hatalmi pozícióikban, így nem meglepő, hogy a sport felső vezetésében is erősen felülreprezentált a férfi nem. Az alrendszerek összefüggése, 'együttmüködése' vitathatatlan. Mindezekkel összefüggésben, az interjúalanyaim valamennyien egybehangzóan állították (sportnyelven szólva), hogy nem egyenlö a nők számára a 'rajtvonal' a sportvezetővé válás terén. Jól működik a "közéleti patriarchizmus", mely strukturális hátrány, egy új akadály a nők számára. Egyes kutatók szerint korunkban az „új tőkék” felértékelődésének lehetünk tanúi (Sik, 2006); tipikusan ilyen a hatalmi/kapcsolati tőke (Putnam, 1993, 2000; Bourdieu, 2000), melyből a nőknek lényegesen kevesebb jutott. Ezzel összefüggésben a nemzetközi women's studies-ban már arról beszélnek, hogy esélyegyenlőség helyett, a „...nemi egyenlötlenségek új formájára számithatunk..." (Eagly és Carli, 2007, in: Kürtösi, 2008, 35.), az új tőkék felértékelődése nyomán.

4. Az "inter pocula", a "bagyományok automatizmusa" és a "közéleti patriarchizmus" kategóriáival bemutatott jelenségek hatása - okozati összefüggések

"Kik sétálnak a 'hatalom folyosóin, a sportban'?" teszi fel a kérdést, a nők sportbeli helyzetét vizsgáló kutatónő (Pfister, 2003, 3.). Az "inter pocula", a "hagyományok automatizmusa ", a "közéleti patriarchizmus" virágzó működése nyomán, a hatalom csúcsain csaknem kizárólag férfiak vannak a sportvezetésben. „A nemzetközi sporttestületekben gyakori az a helyzet, hogy a vezetö beosztásokat férfiak töltik be, akik föként férfiak által dominált országos sportszervezetekböl kerültek kiválasztásra." (Talbot, 2000, 93.). A sportvezetői tisztségekre döntően férfiakból álló testületek választanak, így nem meglepő, hogy ők jellemzően férfitársaikat részesítik előnybe. Az egyik sportvezetőnő interjúalanyom ezt így fogalmazta meg: „...nagyobb arányban férfit fognak választani vezetöjüknek. Ez tényleg ördögi kör, ez ellen nem lehet tenni ...".

Londonban, az olimpián a magyar csapat 40\%a már női versenyző volt. Ezzel szemben a legfelső sportvezetésben, az újjáalakult MOB-ban a 2014es évben az elnökségben két nőt találunk. Ez 11,1 \%-os női reprezentációt jelent az elnökségen belül. 'Token' pozíció (Kanter, 1977); azaz a női érdekérvényesítésre nem alkalmas. Valódi érdekérvényesítéshez, a vezetői tisztségek kb. 30\%-át kellene a nőknek betölteni; ezt nevezi a szakirodalom „kritikus tömegnek" (Dahlerup, 1988). A MOB-ban a legfelső vezetők (elnök, fötitkár) férfiak, mindöszszesen két női bizottságvezető van. Valamit a Női Bizottságnak is nő a vezetője, de ez még nem olyan nagy vívmány. A sportszövetségekben - a honlapok adatai szerint - nem igen találunk első számú vezetőnőt (elnöknőt)! A harminchárom nyári olimpiai sportági szakszövetség egyikében sem volt 2014-ben elnöknő; még elnökhelyettes is alig akadt. Sőt, ezen harminchárom szakszövetség közül tizenhétnél (!), tehát több mint a felénél, egyáltalán nincs nő az elnökségben. Női főtitkár néhány sportszövetségben található. De ők is inkább kivételnek tekinthetők, nem beszélve arról, hogy a fótitkári poszt, mint adminisztratív vezetői tisztség, az esetek nagy részében nem döntéshozói, így nem igazi vezető poszt; sőt, ahogy egyik interjúalanyom fogalmazott: „...ez itt sziszifuszi munka..", azaz hierarchikus alá-fölérendeltségben egy végrehajtói pozíció, így tipikusan 'nöi' munka. A sportvezetés terén ma még nincs esélyegyenlőség a nők számára. A nők a sportvezetésben gyakorlatilag nem léteznek („women virtually non-exsistent”), állapítják meg egy konkrét ország kutatási adatai kapcsán (Pfister, 2003). Az a kevés sportvezetőnő, aki mégis, kivételként, döntéshozó pozícióba került, sportszervezetük vezetésében, 
nőként, vagy teljesen egyedül van, vagy kisebbségként van jelen (token pozíció; Kanter, 1977). A senior pozíciókban jelenlevő kevés nő alacsony számának további magyarázata (oksági összefüggések), éppen az "imparitás faktorokkal" konzervált vezetönői - kisebbségi létben (Hacker, 1951) lelhetö meg; a kisebbségi lét, mint elsődleges strukturális ok (is) magyarázza, hogy nőként nehezebb a hierarchiában való elörejutás. A kisebbségi lét hatása mintegy önmagába záruló körforgás jelentkezik minden szinten: a sportban a nők előrelépése, már alacsonyabb szinteken, a klubok, egyesületek háza táján lemarad a férfiakétól. Az alacsonyabb szinteken (klubok, egyesületek) a vezetéséből hiányzó nők helyzete közvetlen, ok-okozati összefüggést mutat a szakszövetségekből hiányzó nők csekély számát feltáró statisztikai adatokkal. Ma még azért nincs a sport felső vezetésében (szakági sportszövetségek) elegendő nő, mert már alsóbb szinten sem jutnak megfelelő számban a vezetői tisztséghez elengedhetetlen súlyú (középvezetői), azaz „láthatósági” pozícióhoz. Jelen tanulmányban terjedelmi okokból nem térhetünk ki a sportvezetés különböző szintjein a nők helyzetére. Az azonban egyértelműen látszik, a nyilatkozó sportvezetőnők narratíváiból kitűnően is, hogy a sport sem különbözik a többi társadalmi alrendszertől, így a nők jellemzően csak a második vonalig jutnak el a vezetésben (Nagy, 2009). Konkrét üvegplafon számukra a MOB elnöki tisztsége, ahogy azt többen is megfogalmazták. Továbbá, többek percepciója szerint, egyéb MOBbeli (pl.: bizottság vezetöi szint) és a szakszövetségeknél is az egyéb vezetői posztok (elnöki, fötitkári, vezető edzői szint stb.), szintén nehezített 'pálya' a nők számára. A sport felső vezetéséből (sportági szakszövetségek) hiányzó nők pedig, hiátusukkal, okai annak, hogy a sport legfelső szintjén (MOB) rendkívül alulreprezentáltak. A sport különböző szintereiről hiányzó nők, hiátusukkal, saját maguk akadályai nőtársaik vezetővé válásának, esélyeiket csökkentik, egyben tovább erősítik a férfijogú dominanciát (circulus vitiosus). Ahogy azt az egyik megkérdezett sportvezetőnő a MOB-ba kerülés lehetősége kapcsán megfogalmazta: "...de hát kit delegál egy szövetség, csak az elnököt (aki férfi) delegálja, ez a gyürü ez megy, folytonosan igy megy,...és ez hátrányos a nöknek". A kisebbségi lét ilyen formán egyszerre ok és okozat is, egyéni és társadalmi szinten egyaránt. Könnyen belátható, a vezetővé váláshoz - különböző vezetői szinteken - láthatóvá kell válni, jelen lenni. Már a rómaiak megmondták: "esse quam videri" (nem elég létezni, de láttatni kell magunkat). Ennek hiányában fogalmilag kizárt a karrier: aki nem 'látszik', az nem létezik! A sport alsóbb szintjein még látható nők 'eltünnek' a hatalmi piramis lépcsőin. A hatalmi piramis alján leginkább csak nőket látni: a sportegyesületek, sportszövetségek, adminisztratív és ügyintézői állománya döntően nőkből áll. Azonban mennél feljebb haladunk a hatalmi piramis csúcsa felé (szakosztályvezetők, fötitkárok, elnökségi tagok, alelnökök stb.) azt látjuk, egyre kevesebb a nő (üvegplafon jelenség, vertikális szegregáció). A „láthatatlan” nők „láthatatlanságuk” okán súlyos, leküzdhetetlen hátrányba kerülnek, mely személyes karrierjük kezdetén, annak bölcsőjénél ellehetetleníti előrejutásukat. Össztársadalmi méretekben pedig a női nem karrier-esélyeinek egyenlőtlenségét hosszú távon továbbra is fenntartja a „második nem” standard „láthatatlansága”, a negatív előítéletek beidegződése a vezetői kiválasztás során.

\section{Összegzés}

A nők többsége a sportban kimarad döntéshozatali pozíciókból, mert. „... még mindig találkozhatunk nemi alapú karrier akadályokkal, amelyek a nök elörejutását gátolják". (Sümegi, 2007, 43.). A fentiekben, mint "imparitas faktort" (esélyegyenlőtlenségi tényezőt), bemutattam három ilyen, a nők előtt álló karrier akadályt ("inter pocula", "hagyományok automatizmusa", "közéleti patriarchizmus"), melyek a férfiak által dominált sportvezetésben (is) markánsan jelen vannak. Bár tudom, hogy minden új kategória, fogalom ("inter pocula", "hagyományok automatizmusa", sőt maga az "imparitás faktor", mint gyüjtőfogalom) bevezetése, elfogadtatása nehézségeket hordoz; azonban a tudományban (is) előbb-utóbb minden nóvum nyilvánosságra kerül, teret nyer. Célom tehát a problémának és az okokozatok magyarázatának első bemutatása volt, remélve, érvelésem pozitív elfogadókra talál. Minden olyan rendszer, amely igazságtalan, diszkriminatív a nőkkel szemben (és a hatalmi, vezetői tisztségek elosztása jelenleg ilyen) rossz azoknak (a férfiaknak) is, akik működtetik ezt a rendszert. A változásokhoz alapvetően a gondolkodásmód átalakítására lenne szükség a hazai sportvezetésben is; fel- és elismerni, hogy a nők arányos részvétele a vezetésben alapvető emberi igazságosság kifejezése és nem kegy. Nyilvánvaló, a jövőben további erőfeszítésre, a nemek 
egyenlőségét érvényesítő vezetési modellre (gender equality management), ennek megfelelő szemléletre és gyakorlatra van szükség. Stratégiai nőtámogatás (affirmative action) kell; azaz pozitív eszközök (mentorálás, képzések, hálózat építés, stb.), melyek a nőket hátráltató, a nemi akadályok kiküszöbölését vagy legalább azok enyhítését szolgálják.

$\mathrm{Az}$ Európai Unió a sportot (a szabályozását) nemzeti hatáskörbe utalja. Viszont a nők és férfiak közti esélyegyenlőség, mint az Unió egyik alapértéke a sportban, a sportvezetésben is uniós szintű megvalósítandó feladat. Az Európai Bizottság, 2005-2010-re szóló „Jelentés”-ében elöírta, „A nők és férfiak közötti esélyegyenlöség" teendőit; a nemek közötti esélyegyenlőség ügyének valamennyi uniós politikába és tevékenységbe - így a sportpolitikába, sportvezetésbe is - történő beépítését. E körben fokozott hangsúlyt kapott: "a döntéshozatalban a nök és a férfiak egyenlö részvételének elömozdítása", azaz a gender mainstreaming stratégia követelményét fogalmazta meg, várja el a „Jelentés”. Ez az Európai Unió sportpolitikájában konkrétan, az Európai Bizottság ún. „Fehér könyv a sportról” című dokumentumában jelent meg. Ebben az Európai Bizottság ösztönzi a nemek közötti esélyegyenlőség általános érvényesítését minden sporttal kapcsolatos tevékenységben, valamint a nők számára döntéshozó pozíciók elérhetővé tételét a sportban (Nemes, 2009).

Nem hasznossági kérdés, hanem sokkal inkább az igazságosság terültéhez tartozik a nők esélyegyenlőségének biztosítása, azonban nem hagyhatjuk figyelmen kívül azokat a nemzetközi adatokat - noha speciálisan nem sportvállalatok közötti felmérések eredményei -, melyek azt támasztják alá, hogy eredményesebben, nyereségesebben működnek azok cégek, ahol a nők a senior pozícióban is helyet kaptak. A Harvard Business School egyik professzora szerint: a nők azokban a képességekben jobbak, amelyek nélkülözhetetlenek a sikerhez a globalizáció idején, amikor a csapatmunka és a partneri viszony igen fontos (Cibere, 2005). Ugyanezt megtapasztalták azok a sportszervezetek is, ahol női felsővezető működik. Egyik interjúalanyom a férfiak és nők együttműködésére hívta fel a figyelmet, mikor kiemelte: „... nagyon jó lenne, ha a férfiak is felfognák, hogy egy testület sokkal hatékonyabban és sokkal jobban tud úgy müködni, hogyha megosztva vannak benne a különbözö nemü képviselök, mert másként tud hozzátenni egy nö értéket és másként egy férfi, ezért egyik sem nélkülözhetö". A sajátos női értékek, látásmódok (speciális hozzájárulás modellje; Alvesson-Billing, in: Nagy, 2009), jelenléte a sportvezetésben vitathatatlanul többlet értékforrást jelent.

Össztársadalmi érdek tehát, hogy a népesség egyik fele (a női nem) a formális jogi egyenlőségen túl valóban, ténylegesen - esélyeiben, lehetőségeiben - legyen egyenlö; a sportvezetésben is. A fentiekben ismertetett "imparitás faktorok" (I.-III.), igen jól demonstrálják, hogy a nőknek még menynyit kell haladniuk, hogy legalább megközelítsék a férfiakkal való egyenlőséget (Dunning, 2002). „A sport nem engedheti meg magának, hogy figyelmen kivül hagyja a társadalom több mint felének tehetségét..." (Talbot, 2000, 97.).

A teljes megoldást csak a rendszerszintủ változások jelenthetik, melyeket mindenki, férfiak és nők egyaránt akarnak, mert ez mindannyiunk közös érdeke. „Together Stronger: For the Future of Sport” ("Együtt erősebbek vagyunk: a jövő sportjáért" Nők és Sport 5. Világkonferencia jelmondata.).

\section{Felhasznált irodalom}

1. Andorka R.(2006): Bevezetés a szociológiába. Osiris, Budapest.

2. Alvesson, M. - Deetz, S. (1998.): A munkahelyi uralom modern formái, avagy mit üzen a kritikai és a posztmodern gondolkodás a szervezetkutatás számára? (Ford.: Kocsis T.- Baranyi Á.). http://epa.oszk. hu/00700/00721/00003/pmodrov.html

3. Bíró, E. (2008): A nők megjelenítése a legjobb film Oscar-díját,1970-2005 között elnyert filmekben. http://phd.lib.uni-corvinus.hu/619/

4. Budai, K. (2001): Az alma meg a fája. http:// www.magyarpaxromana.hu/tevekenysege/ kongress/43/buday_kornelia.html

5. Bodnár, I. (2012): Azedzöi munka mint nöi foglalkozási életpálya. http://phd.sote.hu/mwp/ phd_live/vedes/export/bodnarilona.d.pdf

6. Bourdieu, P. (2000): Férfiuralom. Napvilág, Budapest.

7. Cibere, I. (2008): Gender ABC; The EQUAL Programme is funded by the European Social Fund and the Hungarian Government. http:// www.szoctanszek.unideb.hu

8. Dunning, E. (2002): A sport, mint férfiaknak fenntartott terület. Korall 7-8, 140-154. (Ford: Lengvári István).

9. Eagly,A.H., Karau,S.J.(2002):RoleCongruity 
Theory of Prejudice Toward Female Leaders. Psychological Review 3, 573-598. http:// dx.doi.org/10.1037//0033-295X.109.3.573

10. Ely, R., Padavic, I. (2007): A feminist analysis of organizational research on sex differences. Academy of Management Review 32:4, 1121-1143 http://dx.doi.org/10.5465/ AMR.2007.26585842

11. Giddens, A. (2008): Szociológia. Osiris, Budapest.

12. Hadas M. (2002): A libido academica narcizmusa; Pierre Bourdieu: Férfiuralomról. Replika 47-48. 175-194.

13. Nagy, B.(1993): Nők a vezetésben. Szociológiai Szemle 3:3-4, 147-166.

14. Nagy B. (2009): Férfiak és nők a vezetésben. in: Nagy I., Pongrácz T. (szerk.): Szerepváltozások. Jelentés a nök és férfiak helyzetéröl 2009. TÁRKI - Szociális és Munkaügyi Minisztérium, Budapest. htpp://www.szmm.gov.hu/

15. Koncz K. (2011): A nők esélye a parlamentben - húsz év távlatából. Esély 2011/1. http:// www.esely.org

16. Kovács K. (2009): Küzdelmek a ringben és azon kívül. Kultúra és közösség 2009/III-IV. 63-77.

17. Kovács K.(2012): Sportoló csoportok a Debreceni Egyetemen. http.//www.campuslet. unideb.hu

18. Nemes, A.(2009): Sportjog jegyzet TF.

19. Pfister, G. (2003): A world power in Women's Sport - Women Without Power in Sport: Gender, Power, and Sport in East Germany. http://www.idrottsforum.org/articles/pfister/ pfister.html

20. Pfister, G., Radtke, S. (2005): Sport, Women and Leadership: Selected Results of the German Project "Women Taking the Lead". http:// www.idrottsforum.org/articles/pfister/pfister_ radtke050503.html

21. Poulsen, A. L., Pfister, G. (2007): Leaders in sport organisations who "dropped out". http:// www. nexs.ku.dk

22. Hargreaves, J. (1985): Playing Like Gentlemen While Behaving Like Ladies; Contradictory Features of the Formative Years of Women's Sport. British Journal of Sports History 2:1, 40-52. http://dx.doi. org/10.1080/02649378508713562

23. Kürtösi, Zs. (2008): Nők és férfiak társadalmi kapcsolati hálózatának eltérései a munka szervezetekben. http://phd.lib.uni-corvinus.hu
24. Sümegi, B. (2007): Nơk a vezetésben, nehézségek és lehetöségek. http://elib.kkf.hu/ edip/D_13900.pdf

25. Talbot, M. (2000): Döntéshozatal a sportban. in: Perényi E.- Berta G. K. (szerk): Nemzetközi tapasztalatok a nők sportjának világából. ISM értesitó 2000/11, 91-116.

26. Théberge, N. (1991): Women and The Olympics: A Consideration of Gender, Sport and Social Change. in: Landry, F., Landry, M., Yerlès, M. (eds): Sport... The Third Millennium: Proceedings of the International Symposium, Quebec City, Canada, May 2125, 1990. Les Presses de l'Université Laval, Quebec. 385-396.

27. Women, Leadership and the Olympic Movement (2004): Final Report (by IOC and Lougborough University), 11-45.

Dokumentumok

1. http//www.eu.hu/europaibizottsag

2. Az Európai Bizottság Nyilatkozata (1988): A nők és férfiak egyenjogúságáról.

3. Az Európai Bizottság Jelentése (2005): A nők és férfiak közötti esélyegyenlőségről 2005 -2010.

4. Documents the European Commission Justice, Fundamental Rights and Citizenship (2011): Positive Action Measures to Ensure Full Equality in Practice between Men and Women.

Weblapok (megtekintve 2013. július 24-25.)

1. www.nemzetisport.hu

2. www.sportgeza.hu

Weblapok (megtekintve 2012. október, november)

1. www.euroinfo.hu

2. www.euvonal.hu

3. www.ioc.org

4. www. mob.hu

5. www.nokmozgasban.com/2010/01/ reszvetel-sportban-es-dontesekben-de-jo. html

Újságok

1. Nők Lapja, 2011/2: Több szoknyát a Parlamentbe.

2. Magyar Nemzet, 2012 aug. 24.: Parajelenség.

3. Magyar Nemzet, 2013 máj. 21.: A.T. továbbra is elnök.

4. Magyar Nemzet, 2013 aug. 24.: Molesztálások, bántalmazások tömkelege. 